\title{
In-vivo Evaluation of Anti-Coccidial Efficacy of Aqueous Extract of Allium sativum and Carica papaya in Experimentally Infected Broiler Chicks
}

\author{
Udo EJ*, Abba AM, Abdulhamid Y and Mudassir I \\ Department of Biological Sciences, Nigerian Defence Academy, Nigeria
}

Submission: August 13, 2018; Published: October 03, 2018

*Corresponding author: Udo EJ, Department of Biological Sciences, Nigerian Defence Academy, P. M. B 2109, Kaduna, Nigeria, Email:amabba89@yahoo.com

Abstract

A study was carried out to evaluate the efficacy of Allium sativum (garlic) and Carica papaya (pawpaw) with respect to growth and PCV value in Eimeria tenella infected broiler chicks. A total of 36 chicks (21 day old) were randomly divided into 9 groups (Group 1-9) of 4 chicks each. All the groups were infected with 5100 viable sporulated oocysts of Eimeria tenella orally except G7 and G8 which served as control. G1 and G2 were treated with supplement of Allium sativum at 10 and $5 \mathrm{ml} / \mathrm{L}$, respectively, G3 were treated with aqueous garlic + pawpaw extracts at $10 \mathrm{ml} / \mathrm{litre}$ in drinking water. G4 and G5 were treated with supplement of Carica papaya extracts at 10 and $5 \mathrm{~g} / \mathrm{L}$, respectively. G6 was treated with Amprolium at $1.25 \mathrm{~g} / \mathrm{L}$ (+ve control) while G9 was Eimeria tenella infected chicks and non-treated (isolated positive control). Data collected were analyzed using analysis of variance (ANOVA) at $\mathrm{P}<0.05$ level of significance. The study showed that treatment with Allium sativum and Carica papaya resulted in marked reduction in the number of coccidian oocysts shed by treated chicks.Even though it was not statistically significant ( $p>0.05$ ), there was an increase in the mean weight and PCV values in the Eimeria tenella infected but treated groups. Thus, the plants extract can be used as alternative of synthetic chemical drugs in combating coccidiosis and improve chicken health.

Keywords: Eimeria tenella; Growth; PCV value;Allium sativum;Carica papaya

\section{Introduction}

Broiler chicken (Gallus gallusdomesticus) is a gallinaceous domesticated fowl, bred and raised specifically for meat production. It is a hybrid of the egg-laying chicken and a subspecies of the red jungle fowl (Gallus gallus) and typically, has white feathers and yellowish skin [1]. Worldwide, consumption surveys indicate that broiler chicken is the second largest consumed meat. Broiler meat accounts for approximately $33 \%$ of world meat intake, serving as the chief meat in consumer diets in many low to middle income countries. Overall, the outlook for global chicken consumption is optimistic as it is expected to increase along with human population and income growth. The total number of broiler meat consumed in the world was nearly 47 billion in 2004; of these, approximately $19 \%$ were consumed in the US, $15 \%$ in China, $13 \%$ in the Europe $25 \%$ and $11 \%$ in Brazil; and Worldwide, 86.6 million tonnes of broiler meat were estimated to be consumed by 2014 [2].Therefore, broiler production as healthy and nutritious when compared to beef and mutton can serve as the keys in bridging the protein in-take gap since broiler chicken meat has lower iron contents [3].

The profession of bird keeping has assumed great importance in improving the employment opportunity and animal food pro duction in the World. It is also regarded as an important means of sustainable livelihood and a way of achieving a certain level of economic independence. Poultry have a significant effect on both international and national economy. Reports showed that about $10 \%$ of Nigerians are engaged in poultry production, mostly on subsistence and small or medium-sized farms [4]. The economic efficiency of poultry production is however challenged with various constraints namely, feed inputs such as protein supplements which are usually expensive, limited access to capital, exploitation of the unconventional ingredients and by-product [5]; and a number of diseases such as new castle disease, infectious bursal disease and Coccidiosis. Among these constraints, coccidiosis has been reported as one of the major problems of poultry industry in the world [6].

Coccidiosis is a disease caused by a single celled obligate parasite belonging to the phylum: Apicomplexa, subclass: Coccidia, and the genus: Eimeria $[7,8]$. In chickens, nine Eimeria spp. have been described and the commonest species are Eimeria tenella, which causes caecal coccidiosis and E. acervulinaas well as E. maxima which cause chronic intestinal coccidiosis [9]. Coccidiosis has still remained one of the most important and common parasitic 
disease to the broiler industry [10]. Infection is caused by different species of Eimeria which invades the mucosal epithelium of the intestines and causes enormous economic losses, particularly by reducing growth rate. Eimeria sporozoites invade the intestinal epithelium and results in inflammation leading to the initiation of the immune response to the production of nitric oxide (NO) and other powerful pro-oxidants that belong to reactive oxygen species (ROS). These compounds are not only toxic for sporulated oocysts but also have negative side effects on the host if not protected by an antioxidant system [11]. To prevent economic losses due to negative effects on production, anticoccidial drugs are used continuously.

In many parts of the world, the use of coccidiostats such as amproliumsulphonamides, quinoline, polyether ionophorous and clopidol in treatment of coccidiosis is very common. However, the increasing resistance of coccidia to currently used anticoccidial drugs [12], coupled with the increasing costs of developing new drugs and the public's distrust of drug-treated meat demonstrate the urgent need to explore alternative methods of controlling this disease. Drug or antibiotic residues in poultry products may inflict toxic effects on the animal health. Therefore, nutritional methods mainly based on natural feed additives are considered to be one of the most promising alternatives to anticoccidials [10].

Several herbal and medicinal plants have been used as coccidiostat in traditional medicine in different parts of the world. These plants include Anona senegalensis, Khaya senegalensis and Butyrospermumparadoxum, Allium sativum and Carica papaya[13-15]. Garlic (Allium sativum) and pawpaw (Carica papaya) have been reported to cure and prevent various diseases in animals (Delaha and Garagusi, 1985). Informations on their efficacy in the treatment of coccidiosis in broiler birds are scanty. Hence this study was designed with the view to evaluate the effects of Allium sativum (garlic) and Carica papaya (pawpaw) extracts on the viability of coccidia oocysts in vivo and its effects on weight and PCV values of coccidia infected broiler chicks.

\section{Materials and Methods}

\section{Collection and Identification of Plant Material}

Fresh Allium sativum and unripe fruits of Carica papaya were bought from an urban market (Chechenia) in Kaduna, Kaduna State. Plant samples were transported in polythene bags to the Department of Biological Sciences Laboratory, Nigeria Defence Academy for identification. In the laboratory, the bulb and fruit of sampled plants were identified by a Botanist and assigned a voucher number.

\section{Preparation of Aqueous Plant Extracts}

Aqueous Allium sativum and Carica Papaya aqueous extract was prepared according to the method of Parekh \& Chanda [16].

\section{Experimental drug}

Commercially available anticoccidial drug (Amprolium) for the treatment of coccidiosis was used to compare the anticoccid- ial efficacy of the aqueous and powder extract of A. sativum and C. papaya.

\section{Collection and Isolation of Eimeria tenellaOocyst}

Fresh faecal samples from chickens naturally infected with Emeria species were collected from the college of Agriculture poultry farm Mando, Kaduna, Kaduna State, Nigeria, using a wide mouth sample bottle. Samples collected were placed on ice in thermox box and transported to the Department of Biological Sciences Laboratory NDA Kaduna. In the Laboratory, faecal sample was transferred to a $50 \mathrm{ml}$ test tube containing $2 \%$ Pottssium Dichromate. Oocysts were isolated using sieving and sedimentation techniques as described by Soulby[17].

\section{Preparation of Eimeria sp.Oocysts for In Vivo Assay}

Isolated oocysts were suspended in $2.5 \%(\mathrm{w} / \mathrm{v})$ potassium dichromate in petri dishes and incubated at room temperature for 7 days in Biological Sciences Laboratory, NDA. After 7 days sporulation, oocysts were recovered by centrifugation at 3,000 rpm for $5 \mathrm{~min}$ in saturated sodium chloride solution followed by washing in distilled water. Sporulated oocysts were then quantified using Mc Master counting chamber and diluted in distilled water to make a suspension of 5100 oocysts per ml.This was kept at room temperature until needed.

\section{Experimental Chicks and Design of the Study}

Thirty-six (36) 2-weeks old broiler chicks were purchased and were kept for 1 week to acclimatize during which each bird was observed carefully for signs of infection. Faecal samples were also collected from birds daily and examined microscopically for signs of cocciodiosis. The thirty-six (36) broiler chicks were randomly divided at $21^{\text {st }}$ day of age into 9 groups (Group 1-9) of four (4) chicks each. Detailed grouping of chicks were as follows:

Group 1:Eimeria tenellainfected chicks were treated with aqueous garlic extracts at $10 \mathrm{ml} /$ litre in drinking water.

Group 2:Eimeria tenellainfected chicks were treated with aqueous garlic extracts at $5 \mathrm{ml} /$ litre in drinking water.

Group 3:Eimeria tenellainfected chicks were treated with aqueous garlic + pawpaw extracts at $10 \mathrm{ml} /$ litre in drinking water.

Group 4:Eimeria tenellainfected chicks were treated with aqueous pawpaw extracts at $10 \mathrm{ml} /$ litre in drinking water.

Group 5:Eimeria tenellainfected chicks were treated with aqueous pawpaw extracts at $5 \mathrm{ml} /$ litre in drinking water.

Group 6:Eimeria tenellainfected chicks were treated with Amprolium powder at $1.5 \mathrm{~g} /$ liter drinking water.

Group 7: Non-infected and non-treated (negative control).

Group 8:Non-infected but supplemented with garlic extracts + pawpaw extract.

Group 9:Eimeria tenellainfected chicks and non-treated (isolated positive control). 
All groups except group 7 and 8 (unifected control) were infected with 5100 sporulated oocystsorallythroughdrinking waterby gavage at 21 day old age. Treatment of chicks in all groups commenced on the 3rd day of post experimental infection following the detection of occyst in the faeces and presentations of clinical manifestations after 3 days post infection, and subsequently therafteron a daily basis until the experiment was terminated on the $11^{\text {th }}$ day.Treatment with crude extracts was achieved in birds after thirst of $1 \mathrm{hr}$.

\section{Clinical Examination}

Clinical signs such as depression, ruffled feathers, bloody diarrhea and loss of appetite were recorded during experimental period.

\section{Determination of Oocyst Count}

Fresh faecal droppings were collected from the litter spread on the ground from each groups for oocysts count daily from the day of commencement of treatment till the $11^{\text {th }}$ day when the experiment was terminated. The mean number of oocyst per gram of faeces for each group was determined using a modified Mc Master counting chamber.

\section{Determination of Live Weight of Chicks}

Birds in all the groups were weighed in grams (g) on a daily basis using weighing balance (spring balance) scale. Mean weights from each replication were also recorded to establish the growth rates against the expected normal growth curve of a broiler.

\section{Determination of Packed Cell Volume (PCV)}

Packed cell volume (PCV) of birds in all the groups was determined as described by Slaoui\&Fiette[18]using duplicate capillary tubes. Blood samples were collected from each chicken in all the groups through their wings with the help of $5 \mathrm{ml}$ syringe. The blood were filled in capillary tubes at three quarter level and then sealed at one end with wax. The sealed capillary tubes were then centrifuged at $12,000 \mathrm{rpm}$ at $10 \mathrm{~min}$ in a microhaematocrit centrifuge (Hawksley MHC) read using the Hawksley haematocrit reader and expressed in percentage.

\section{Data Analysis}

Data generated from the study was analyzed using Statistical Package for Social Scientist (SPSS) version II (2011). Analysis of variance was used to determine significance between groups; simple percentage was used to determine percentage reduction while least significant difference (LSD) was calculated at $\mathrm{p} \leq 0.05$.

\section{Results}

\section{Clinical Presentations of Coccidiosis in Infected and Treated Birds}

Birds in all infected groups had ruffled feathers, decrease appetite, depression and paralysis, in some cases by day 3 post infections. Bloody diarrhea (stool) was passed by infected birds on the $4^{\text {th }}$ day post infection. Maximum presentations of these clinical signs were observed at day 7 and 9 post infection. However, there was regression and disappearance of bloody diarrhoea afterwards till the end of the experiment on day 12. In groups 1-6 (G1, G2, G3, G4, G5 and G6) treated with different concentrations of A. sativum and C. papaya either as aqueous extract or powder preparation, manifestations of symptoms of coccidiosis became milder as treatment progressed. However, birds in G5 treated with $5 \mathrm{ml} / \mathrm{l}$ of C. papaya showed evidence of depression, decrease feed intake, and persistence of bloody diarrhoea and death of $25 \%$ of the birds at day 3 through 7 of treatment period. Birds in Gr 9 that formed the infected non-treated group were observed to have ruffled feathers, decrease appetite, depression, bloody diarrhea and paralysis which persist all through the experimental periodresulting in the death ofbirds in this group.

\section{Effects of Aqueous Extracts of A. Sativum and C. papaya treatment on E. tenellaOocyst Counts in Infected Birds}

Table 1: Effects of Aqueous Extracts of A. Sativum and C. papaya treatment on E. tenellaOocyst Counts in Infected Birds.

\begin{tabular}{|c|c|c|c|c|c|c|c|c|c|}
\hline \multicolumn{10}{|c|}{ Oocyst Counts (Mean \pm SD) Group } \\
\hline TD & $\mathbf{1}$ & $\mathbf{2}$ & $\mathbf{3}$ & $\mathbf{4}$ & $\mathbf{5}$ & $\mathbf{6}$ & $\mathbf{7}$ & $\mathbf{8}$ & $\mathbf{9}$ \\
\hline 4 & $156.5 \pm 4.6 \mathrm{a}$ & $139 \pm 28.8 \mathrm{a}$ & $137.3 \pm 43 \mathrm{a}$ & $175 \pm 61.4 \mathrm{a}$ & $145 \pm 28.9 \mathrm{a}$ & $168 \pm 27.5 \mathrm{a}$ & $00 \pm 00 \mathrm{~b}$ & $00 \pm 00 \mathrm{c}$ & $170 \pm 24.5 \mathrm{a}$ \\
\hline 5 & $1932.5 \pm 627 \mathrm{a}$ & $1457.5 \pm 81 \mathrm{~b}$ & $1507.4 \pm 78$ & $1915 \pm 596 \mathrm{c}$ & $1500 \pm 57.2 \mathrm{a}$ & $1985 \pm 501 \mathrm{c}$ & $00 \pm 00 \mathrm{~d}$ & $00 \pm 00 \mathrm{e}$ & $2080 \pm 283 \mathrm{f}$ \\
\hline 6 & $3740 \pm 175.1 \mathrm{a}$ & $3465 \pm 445.2 \mathrm{a}$ & $2075 \pm 298.6 \mathrm{~b}$ & $2490 \pm 547.1 \mathrm{c}$ & $3216 \pm 107 \mathrm{~d}$ & $3012.5 \pm 589 \mathrm{~d}$ & $00 \pm 00 \mathrm{e}$ & $00 \pm 00 \mathrm{e}$ & $3460 \pm 57.8 \mathrm{f}$ \\
\hline 7 & $1100 \pm 216 \mathrm{a}$ & $1812.3 \pm 473.2 \mathrm{~b}$ & $1275 \pm 359 \mathrm{c}$ & $1556.3 \pm 347.6 \mathrm{~b}$ & $2480 \pm 537 \mathrm{~d}$ & $678.8 \pm 150 \mathrm{e}$ & $00 \pm 00 \mathrm{f}$ & $00 \pm 00 \mathrm{f}$ & $4380 \pm 00 \mathrm{~g}$ \\
\hline 8 & $515 \pm 113.5 \mathrm{a}$ & $1227.5 \pm 433.2 \mathrm{~b}$ & $740 \pm 192.3 \mathrm{c}$ & $775 \pm 117.3 \mathrm{~d}$ & $1242 \pm 76.8 \mathrm{e}$ & $6.5 \pm 6 \mathrm{f}$ & $00 \pm 00 \mathrm{~g}$ & $00 \pm 00 \mathrm{~g}$ & $4450 \pm 00 \mathrm{~h}$ \\
\hline 9 & $152.7 \pm 28.3 \mathrm{a}$ & $792 \pm 172.8 \mathrm{~b}$ & $402.8 \pm 178.8 \mathrm{c}$ & $607.5 \pm 95 \mathrm{c}$ & $1038 \pm 57.9 \mathrm{~d}$ & $00 \pm 00 \mathrm{e}$ & $00 \pm 00 \mathrm{e}$ & $00 \pm 00 \mathrm{e}$ & $4880 \pm 00 \mathrm{f}$ \\
\hline 10 & $2 \pm 2.5 \mathrm{a}$ & $538.2 \pm 90.9 \mathrm{~b}$ & $227.8 \pm 101.5 \mathrm{c}$ & $401 \pm 68.4 \mathrm{~b}$ & $828 \pm 67.5 \mathrm{~b}$ & $00 \pm 00 \mathrm{~d}$ & $00 \pm 00 \mathrm{~d}$ & $00 \pm 00 \mathrm{~d}$ & $5560 \pm 00 \mathrm{~h}$ \\
\hline 11 & $0 \pm 0 \mathrm{a}$ & $278.5 \pm 33.2 \mathrm{~b}$ & $46 \pm 30.4 \mathrm{a}$ & $65 \pm 22.9 \mathrm{c}$ & $446.6 \pm 49.3 \mathrm{~b}$ & $00 \pm 00 \mathrm{a}$ & $00 \pm 00 \mathrm{a}$ & $00 \pm 00 \mathrm{a}$ & $5654 \pm 0 \mathrm{~d}$ \\
\hline 12 & $0 \pm 0 \mathrm{a}$ & $37.8 \pm 8.4 \mathrm{a}$ & $1.5 \pm 2.3 \mathrm{a}$ & $3.7 \pm 4.5 \mathrm{a}$ & $1106 \pm 26.5 \mathrm{~b}$ & $00 \pm 00 \mathrm{a}$ & $00 \pm 00 \mathrm{a}$ & $00 \pm 00 \mathrm{a}$ & $5920 \pm 0 \mathrm{c}$ \\
\hline
\end{tabular}

TD: Treatment Days, Values are means \pm standard deviation. Mean values with different letters at the same row differ significantly

The Effects of Allium sativum and Carica papaya crude aqueous extracts on E. tenellaoocyst count in infected and treated birds is presented in Table 1. Despite the treatments given to birds in all treatment groups, oocyst counts increased steadily from day 1-3, including control group treated with Amprolium. However, there was a significant drop in oocysts count in all treated groups (G1- 
G5) on the 4th day of treatment $(\mathrm{P} \leq 0.05)$. A significant increase $(5920 \pm 00)$ was also observed in total oocysts count in G9 (infected non-treated group) when compared to other groups. Moreover,


G6 (678.8 1150.9) compared with other supplemented groups (G2, G3, G4 \&G5) and G9 (infected, non-treated group) (1812.3 \pm 473.2 , $1275 \pm 359,1556.3 \pm 347.6 \& 2480 \pm 537$ and $4380 \pm 00$ respectively) at the first day of post treatment. In comparing various groups

Percentage Reduction in Oocysts Count of Infected Birds Treated with Crude Extracts of Allium Sativum and CaricaPapaya

Table 2: Reduction in the oocysts count of infected chicks treated with crude extracts.

\begin{tabular}{|c|c|c|c|c|}
\hline \multicolumn{5}{|c|}{ Mean Oocyst Counts (Mean \pm SD) } \\
\hline Group (\%) & Interval Days & Pre-Treatment & Post-Treatment & Reduction \\
\hline \multirow[t]{5}{*}{1} & 1 & $3740 \pm 175.1$ & $1100 \pm 216$ & 70.5 \\
\hline & 2 & $"$ & $515 \pm 113.5$ & 86 \\
\hline & 3 & $"$ & $152.7 \pm 28.3$ & 95.9 \\
\hline & 4 & $"$ & $2 \pm 2.5$ & 99.9 \\
\hline & 5 & $"$ & $0 \pm 0$ & 100 \\
\hline \multirow[t]{6}{*}{2} & 1 & $1812.3 \pm 473.2$ & $1227.5 \pm 433.2$ & 47 \\
\hline & 2 & " & $792 \pm 172.8$ & 64.5 \\
\hline & 3 & $"$ & $538.2 \pm 90.9$ & 77.1 \\
\hline & 4 & $”$ & $3465 \pm 445.2$ & 84.5 \\
\hline & 5 & $"$ & $278.5 \pm 33.2$ & 91.9 \\
\hline & 6 & $"$ & $37.8 \pm 8.4$ & 98.9 \\
\hline \multirow[t]{6}{*}{3} & 1 & $2075 \pm 298.6$ & $1275 \pm 359$ & 38.5 \\
\hline & 2 & $"$ & $740 \pm 192.3$ & 64.3 \\
\hline & 3 & $"$ & $402.8 \pm 178.8$ & 80.6 \\
\hline & 4 & $"$ & $227.8 \pm 101.5$ & 89 \\
\hline & 5 & $"$ & $46 \pm 30.4$ & 97.8 \\
\hline & 6 & $"$ & $1.5 \pm 2.3$ & 99.9 \\
\hline \multirow[t]{6}{*}{4} & 1 & $2490 \pm 547.1$ & $1556.3 \pm 347.6$ & 37.5 \\
\hline & 2 & $"$ & $775 \pm 117.3$ & 68.9 \\
\hline & 3 & $"$ & $607.5 \pm 95$ & 75.6 \\
\hline & 4 & $"$ & $401 \pm 68.4$ & 83.9 \\
\hline & 5 & $"$ & $65 \pm 22.9$ & 97.3 \\
\hline & 6 & $"$ & $3.7 \pm 4.5$ & 99.8 \\
\hline \multirow[t]{6}{*}{5} & 1 & $3216 \pm 107$ & $2480 \pm 537$ & 22.9 \\
\hline & 2 & $"$ & $1242 \pm 76.8$ & 61.3 \\
\hline & 3 & $"$ & $1038 \pm 57.9$ & 67.7 \\
\hline & 4 & $"$ & $828 \pm 67.5$ & 74.2 \\
\hline & 5 & $"$ & $446.6 \pm 49.3$ & 86.1 \\
\hline & 6 & $"$ & $110 \pm 26.5$ & 96.5 \\
\hline \multirow[t]{3}{*}{6} & 1 & $3012.5 \pm 589.3$ & $678.8 \pm 150$ & 78 \\
\hline & 2 & $"$ & $6.5 \pm 6$ & 99.7 \\
\hline & 3 & $”$ & $0 \pm 0$ & 100 \\
\hline
\end{tabular}

The percentage Reduction in oocysts count of infected birds treated with crude extracts of Allium sativum and Carica papaya is presented in Table 2. Group 1 (treated with Allium sativum) showed a progressive higher percentage oocyst reduction counts treated with different concentrations of the extracts, there a was a significant difference when comparing the two groups treated with garlic extract (G1\&G2), and the two different concentrations of papaya extract (G4\&G5) they also differed significantly at $(\mathrm{P} \leq 0.05)$, there was no significant difference in comparing the two extracts at $(\mathrm{P}>0.05)$. Garlic supplemented at $10 \mathrm{ml} / \mathrm{liter}$ and $\mathrm{Am}-$ prolium induced high reduction in total oocyts count. 
with $68.9 \%$ and achieved a reduction with $99.8 \%$ at the 12 th day of post treatment. The difference was no t statistically significant at $p \leq 0.05$. Amprolium group achieved a significant $(p \leq 0.05)$ oocyst reduction count with $100 \%$ at the 9 th day post treatment.

\section{Daily Mean Live Weight of Coccidia Infected Chicks Treated with Different Concentrations of Aqueous Extract of Allium Sativum and Carica papaya}

The daily mean live weight of coccidia infected chicks treated with different concentrations of aqueous extract of A. sativum and
C. papaya is presented in Table 3. Birds in groups 1-8 exhibited significant increase in weight ranging from $425 \pm 26.8 \mathrm{~g}-547 \pm 69 \mathrm{~g}$ $(\mathrm{p} \leq 0.05)$ from day 1 through day 11 when treated with different extract concentrations at $2.5 \mathrm{ml}, 5.0 \mathrm{ml}$ and $10 \mathrm{ml}$ or Amprolium given at $1.5 \mathrm{ml}$. However, birds in group 9 which served as infected and untreated control showed a significant decrease in live weight from day 5 till the experiment was terminated on day $11(\mathrm{p} \leq 0.05)$. The loss in mean live weight of birds in Group 9 when compared to other birds in either of the treated groups (1-8) was in range of $112 \pm 59 \mathrm{~g}-154 \pm 72 \mathrm{~g}$.

Table 3: Daily Mean Live Weight of Coccidia Infected Chicks Treated with Different Concentrations of Aqueous Extract of Allium Sativum and Carica papaya.

\begin{tabular}{|c|c|c|c|c|c|c|c|c|c|}
\hline \multicolumn{10}{|c|}{ Mean Live Weight in grams ( \pm SD) Group } \\
\hline Day & 1 & 2 & 3 & 4 & 5 & 6 & 7 & 8 & 9 \\
\hline 1 & $437.5 \pm 47.9 a$ & $432.5 \pm 78 a$ & $442.5 \pm 29.8 a$ & $457.5 \pm 33 a$ & $437.5 \pm 25 a$ & $425 \pm 26.8 \mathrm{a}$ & $425 \pm 64.5 a$ & $465 \pm 72 . a$ & $462 \pm 94 . a$ \\
\hline 2 & $455.8 \pm 55.9 \mathrm{a}$ & $438 \pm 81 \mathrm{a}$ & $451 \pm 32.5 a$ & $458 \pm 34.8 \mathrm{a}$ & $440.3 \pm 24.9$ an & $429.5 \pm 26.7 \mathrm{a}$ & $429.5 \pm 64 a$ & $470 \pm 73 a$ & 467.8 $\pm 95 . a$ \\
\hline 3 & $460.7 \pm 57.4 \mathrm{a}$ & $447 \pm 89.1 \mathrm{a}$ & $464.3 \pm 36.3 a$ & $467.5 \pm 38.6 a$ & $443.3 \pm 26.2 \mathrm{a}$ & $432 \pm 26.8 \mathrm{a}$ & $434.5 \pm 63 a$ & $474 \pm 73.7 \mathrm{a}$ & $472.7 \pm 95.2 \mathrm{a}$ \\
\hline 4 & $461.3 \pm 57.2 \mathrm{a}$ & $448 \pm 88.5 a$ & $458 \pm 32.3 a$ & $467.8 \pm 38.8 \mathrm{a}$ & $443.5 \pm 26.4 a$ & $433.3 \pm 26.4 \mathrm{a}$ & $441.5 \pm 63.6 \mathrm{a}$ & $483 \pm 71.9 a$ & $473 \pm 96.5 a$ \\
\hline 5 & $460.7 \pm 57.7 \mathrm{a}$ & $447 \pm 88.2 \mathrm{a}$ & $456.7 \pm 31.8 \mathrm{a}$ & $466.7 \pm 37.9 \mathrm{a}$ & $442.8 \pm 26.6 a$ & $431 \pm 25.7 \mathrm{a}$ & $447.3 \pm 64.1 \mathrm{a}$ & $490.7 \pm 69.8 a$ & $423 \pm 29.9 \mathrm{a}$ \\
\hline 6 & $458.8 \pm 58.5 a$ & $445.3 \pm 87.6 a$ & $455.3 \pm 32 \mathrm{a}$ & $465.5 \pm 37.5 a$ & $436.3 \pm 29.7 a$ & $430.3 \pm 26 a$ & $454 \pm 67.3 a$ & $494.8 \pm 71.2 \mathrm{a}$ & $421 \pm 30 a$ \\
\hline 7 & $458.5 \pm 60 \mathrm{a}$ & $445.5 \pm 87.8 \mathrm{a}$ & $455.5 \pm 31.5 a$ & $465.3 \pm 37 \mathrm{a}$ & $434 \pm 29.5 a$ & $430 \pm 25.9 a$ & $464.5 \pm 64.2 \mathrm{a}$ & $506.7 \pm 73 b$ & $400 \pm 00 \mathrm{a}$ \\
\hline 8 & $461.7 \pm 59.8 a$ & $447 \pm 87.1 \mathrm{a}$ & $457.3 \pm 31.3 a$ & $466.5 \pm 36.9 \mathrm{a}$ & $434.3 \pm 28.8 a$ & $435 \pm 27.2 \mathrm{a}$ & $473 \pm 69.5 a$ & $517 \pm 73.3 b$ & $390 \pm 00 a$ \\
\hline 9 & $464.2 \pm 59.5 a$ & $448.7 \pm 86.7 a$ & $458.3 \pm 32.5 \mathrm{a}$ & $466.7 \pm 32.9 a$ & $435.6 \pm 29.1 \mathrm{a}$ & $439 \pm 26.6 a$ & $483.2 \pm 71.2 \mathrm{a}$ & $524 \pm 69.6 b$ & $382 \pm 00 c$ \\
\hline 10 & $467 \pm 51.4 \mathrm{a}$ & $450 \pm 86.5 \mathrm{a}$ & $460.3 \pm 31.5 a$ & $472 \pm 36.5 a$ & $438 \pm 29.2 \mathrm{a}$ & $445.3 \pm 26.9 a$ & $501 \pm 68.1 b$ & $536.8 \pm 71.3 b$ & $371 \pm 00 \mathrm{c}$ \\
\hline 11 & $473 \pm 59.4 a$ & $453.2 \pm 87 a$ & $464.3 \pm 31.9 a$ & $476 \pm 36.5 a$ & $442 \pm 28.6 a$ & $452.2 \pm 27.5 a$ & $515.7 \pm 72.8 b$ & $547 \pm 69 b$ & $361 \pm 00$ \\
\hline
\end{tabular}

Values are means \pm standard deviation. Mean values with different letters at the same row differ significantly.

\section{Effects of Treatment on the Daily Packed Cell Volume of Chickens Infected with Eimeria tenella}

The haematological parameters for Eimeria-infected chickens treated with A. sativum and C. papaya crude extracts is presented in Table 4. Values of PCV increased in chicks of groups 1-7 during the first three (3) days of the experiment and then decreased from day 4 through to the 7 th day, and then increased again from day 8 till the experiment was terminated on day 11. In group 6 treated with Amprolium at 1.5g, there was progressive increase in PCV from day 1 through today 12. However, chicks in Gr9 that were infected but not treated (control) exhibited a steady decrease in PCV from $36.06 \% \pm 00.23$ to $16.66 \% \pm 00$. Although the variation in PCV values within each group did not show any significant difference, the variation in PCV values of chicks in Gr 9 was found to be significant $(\mathrm{p} \leq 0.05)$.

Table 4: Effects of Treatment on the Daily Packed Cell Volume of Chickens Infected with Eimeria tenella.

\begin{tabular}{|c|c|c|c|c|c|c|c|c|c|}
\hline \multicolumn{10}{|c|}{$($ Mean \pm SD) PVC (\%) Group } \\
\hline Day & 1 & 2 & 3 & 4 & 5 & 6 & 7 & 8 & 9 \\
\hline 1 & $35.68 \pm 0.40 \mathrm{a}$ & $35.68 \pm 0.40 \mathrm{a}$ & $36.23 \pm 0.29 a$ & $35.86 \pm 0.46 a$ & $36.21 \pm 0.7 a$ & $35.70 \pm 0.34 \mathrm{a}$ & $35.98 \pm 0.013 a$ & $35.81 \pm 0.17 \mathrm{a}$ & $36.06 \pm 0.23 a$ \\
\hline 2 & $35.68 \pm 0.40 \mathrm{a}$ & $35.96 \pm 0.39 a$ & $36.23 \pm 0.029 a$ & $35.86 \pm 0.46 a$ & $36.21 \pm 0.70 \mathrm{a}$ & $35.71 \pm 0.34 \mathrm{a}$ & $35.99 \pm 0.13 \mathrm{a}$ & $35.81 \pm 0.17 \mathrm{a}$ & $36.06 \pm 023 a$ \\
\hline 3 & $35.68 \pm 0.40 \mathrm{a}$ & $35.90 \pm 0.39 \mathrm{a}$ & $36.23 \pm 029 a$ & $35.86 \pm 0.46 a$ & $36.21 \pm 0.71 \mathrm{a}$ & $35.7 \pm 0.34 \mathrm{a}$ & $35.99 \pm 0.13 \mathrm{a}$ & $35.83 \pm 0.17 \mathrm{a}$ & $36.06 \pm 0.23 \mathrm{a}$ \\
\hline 4 & $34.77 \pm 0.40 \mathrm{a}$ & $34.99 \pm 0.7 \mathrm{a}$ & $34.75 \pm 0.86 \mathrm{a}$ & $34.6 \pm 0.90 \mathrm{a}$ & $34.88 \pm 0.46 \mathrm{a}$ & $34.83 \pm 0.27 \mathrm{a}$ & $36.00 \pm 0.13 \mathrm{a}$ & $35.84 \pm 0.17 \mathrm{a}$ & $34.59 \pm 0.34 \mathrm{a}$ \\
\hline 5 & $33.40 \pm 0.35 a$ & $33.23 \pm 0.59 a$ & $32.97 \pm 0.40 \mathrm{a}$ & $32.55 \pm 0.63 a$ & $33.26 \pm 0.32 \mathrm{a}$ & $33.03 \pm 0.68 a$ & $36.01 \pm 0.13 a$ & $35.81 \pm 0.17 \mathrm{a}$ & $32.85 \pm 0.65 a$ \\
\hline 6 & $30.36 \pm 0.44 \mathrm{a}$ & $30.01 \pm 0.43 a$ & $30.50 \pm 0.21 \mathrm{a}$ & $30.09 \pm 0.59 a$ & $29.95 \pm 0.70 a$ & $30.81 \pm 0.62 \mathrm{a}$ & $35.99 \pm 0.13 b$ & $35.81 \pm 0.17 \mathrm{~b}$ & $29.96 \pm 1.00 \mathrm{a}$ \\
\hline 7 & $29.80 \pm 0.15 a$ & $29.06 \pm 0.04 \mathrm{a}$ & $29.39 \pm 0.28$ & $29.25 \pm 0.30 a$ & $28.59 \pm 0.50 a$ & $30.16 \pm 0.14 a$ & $36.0 \pm 0.13 b$ & $35.82 \pm 0.17 \mathrm{~b}$ & $18.86 \pm 0.91 c$ \\
\hline 8 & $30.35 \pm 0.26 \mathrm{a}$ & $30.18 \pm 0.48 a$ & $29.80 \pm 0.31 \mathrm{a}$ & $29.99 \pm 0.02 \mathrm{a}$ & $29.99 \pm 0.04 a$ & $30.93 \pm 0.70 \mathrm{a}$ & $36.00 \pm 0.13 b$ & $35.81 \pm 0.17 \mathrm{~b}$ & $19.01 \pm 00 \mathrm{c}$ \\
\hline 9 & $30.73 \pm 0.43 a$ & $29.76 \pm 0.34 a$ & $29.97 \pm 0.37 a$ & $30.17 \pm 0.55 \mathrm{a}$ & $29.00 \pm 0.10 \mathrm{a}$ & $31.19 \pm 0.80 \mathrm{a}$ & $36.0 \pm 0.13 b$ & $35.81 \pm 0.017 \mathrm{~b}$ & $17.01 \pm 00 \mathrm{c}$ \\
\hline 10 & $30.89 \pm 0.09 a$ & $30.19 \pm 0.42 a$ & $30.09 \pm 0.66 a$ & $30.74 \pm 0.44 a$ & $29.27 \pm 0.31 \mathrm{a}$ & $31.03 \pm 0.62 \mathrm{a}$ & $36.0 \pm 0.13 b$ & $35.81 \pm 0.17 \mathrm{~b}$ & $16.7 \pm 00 \mathrm{c}$ \\
\hline 11 & $30.89 \pm 0.29 a$ & $30.63 \pm 0.43 a$ & $30.49 \pm 0.57 \mathrm{a}$ & $31.91 \pm 0.22 \mathrm{a}$ & $29.62 \pm 0.42 \mathrm{a}$ & $31.35 \pm 0.49 a$ & $36.00 \pm 0.13 b$ & $35.98 \pm 0.13 b$ & $16.66 \pm 00 c$ \\
\hline
\end{tabular}

Values are means \pm standard deviation. Mean values with different letters at the same row differ significantly. 


\section{Discussion}

The clinical signs of coccidiosis in chicks observed during the In vivo study include weakness, reduced appetite, ruffled feathers and bloody diarrhea. These are signs normally associated with coccidiosis in infected chickens. Some of these manifestations are evidence of cumulative tissue damage associated with second or third generation schizogony of the parasite and depends on many factors such as parasite species, viability, infectivity, virulence, tropism, host age, nutritional status and immunological competence.El bana et al. [19] reported the association of the detrimental effect of coccidiosis and manifestation of clinical signs which resulted in mortality of severely affected bird.

Allium sativum and Carica papaya extracts induced anticoccidial effect as evident in the oocyst output in treated groups. In this study, despite the treatments given to birds in all treatment groups, oocyst counts increased steadily from day 1-3, including control group treated with Amprolium. However, there was a significant drop in oocysts count in all treated groups on the 4th day of treatment. This is line with the finding of Biu et al. [20] who reported consistent decreases in faecal oocyst count over 4 days of treatment and at all doses of neem (Azadirachtaindica) in broiler chickens infected with Eimeria species. Garlic supplemented group at $10 \mathrm{ml} /$ liter showed high reduction in total oocyts count. This suggests that the effect of the plant extract on coccidian oocyst output was dose dependent. This cannot be unconnected with the work of El-Khtam et al. [14]\&Biu et al. [20] who reported similar dose related responses in faecal oocyst count and mortality from coccidian infection in broiler chickens. There was observed differential oocyst output between extract treated groups and the control. Amprolium group achieved a significant oocyst reduction count with $100 \%$ at the 9 th day post treatment. This confirms the work of El-Khtam et al. [14], Nghonjuyi et al. [15]\&Tan and Long [21], who reported lowest range of faecal oocyst output in the group treated with amprolium.

Percentage reduction in oocysts count could also probably be due to inhibition or impairment of invasion and or replication and development of Eimeria parasites species in the gut tissues of chicks treated with plant extracts leading to relatively non-viable oocysts formation and release. In other words, the effect of the extracts may be on the intracellular stages of the parasite especially at the 2nd schizogony stage (late stages of asexual cycle) as well as those of the sexual stage of parasite in the lumen of the intestine. It could also be attributed to the effect of antioxidant present in both the plants evaluated in this study. Antioxidants are reported to be responsible for the control of Eimeria infections during oxidative stress and lipid peroxidation of the intestinal mucosa tissues. Allen et al. [22] reported that antioxidant-rich plants is lethal to coccidia parasites due to induced oxidative stress and neutralization of reactive oxygen species which makes it effective in treating coccidial infections. According the author, antioxidant compounds are known to reduce the severity of Eimeria tenellainfections by ameliorating the degree of intestinal lipid peroxidation. Allen and
Danforth (1998) in a separate study concluded that feed supplementations with products that have antioxidant properties such as the pawpaw even at $1 \%$ appears effective in reducing upperand mid-small intestinal infections caused by E. tennela. Similarly, Allen et al. [23] reported that drinking water supplemented with different concentrations of pawpaw extract was suppressive towards the development of coccidiosis in chickens.

In addition, presence of phenolic compounds in the plant extracts evaluated in the study could also have contributed to the lower oocysts count recorded in the infected and treated groups. Sikkema et al. [24] confirmed that phenols interact with cytoplasmic membranes and change their cation permeability leading to impairment of crucial processes in coccidia cells and finally leading to their death. According to Allen et al. [23] C. papaya is rich in phenolic compound which has been shown to have antioxidative, anti-inflammatory and immunomodulatory properties and thus could have responsible for the anticoccidial effects of $\mathrm{C}$. papaya observed in this study. However, the significant reduction in oocysts count in the infected groups treated with A. sativum may be associated with the presence of organosulfur compounds as earlier suggested in the studies. These compounds are found abundantly in A. sativum. Organosulfur compounds are the most important component responsible for most of pharmacological effects of the plant (garlic) [25]. Nghonjuyi et al. [15] support that the anti-inflammatory property of the C. papaya leaves with high concentrations of vitamin A might have acted in caecal epithelium cell protection which is detrimental to the coccidial reproductive activities.

The weights of the treated birds reduced and subsequently increase following the progressive treatment. These variations could be attributed to the deleterious effect of the infection before treatment. Birds affected with coccidian parasite when not treated show progressive signs ill health such as poor weight gain or weight loss, weakness and emaciation and in severely affected birds may result in death after the appearance of disease. The progressive decrease in the weight before treatment occurred probably as a result of severity of the infection. Conway et al. [26],McDougald [27] \&Chapman et al. [28] confirmed that under conditions of more severe infection with Eimeria, weight gain is generally reduced. Conway et al. [26] reported significant reduction in body weight of broilers infected with high doses of sporulated oocysts of $E$. tenella. The improved growth performance by the 4th day of treatment may be related to reduce severity of the infection due to the administration of plant extracts.

The results obtained also showed that infection had no significant effects on the PCV values between extract treated groups.This however support the findings of Nghonjuyiet al. [15] who reported no significant difference between Eimeria infected chickens treated with ethanolic extracts of C. papaya leaves. Similarly, Jatau et al. [29] also recorded no significant differences in the haematological parameters of chickens in an experiment they carried out with experimental fowls. However, the effects of the treatment on 
infected birds could be best appreciated when weights of chicks in the treated group is compared with birds in the untreated group (control). Birds in group 9 progressively lost weight till the end of the experiment. In other words, growth of birds in this group was adversely affected by coccidiosis. This is also reflected by the continuous decrease inPCV values due probably to continuous loss of blood due to passing out of bloody diarhoea which is characteristic of coccidia infected birds. This invariably results in reduced blood count in the birds of group 9. Coccidia parasite such as $E$. tenella is reported to undergo series of intestinal invasions during asexual reproduction resulting in the damage of the intestinal lumen during the course of penetrating the epithelial cells of the caecum and severe erosion of the mucosal membranes through cell lysis which lead to profuse watery-to-bloody diarrhea $[13,20]$. Bloody diarhoea has been reported to have a detrimental effect on the blood parameters of birds including PCV which may lead to anaemia in infected birds [26].

\section{Conclusion}

The results of this study suggest that supplementation with crude extracts of garlic and pawpaw at concentrations of $10 \mathrm{ml} /$ litre drinking water alleviates the negative impact of Eimeria infection in broiler chickens. The beneficial effect of the extract on the number of oocysts per gram of excreta of the infected chickens was found to be optimally effective though not as comparable to that exhibited by Amprolium. Allium sativum exhibits a significant anticoccidial activity than C. papaya although both plants could serve as alternative to synthetic chemical drugs used in combating coccidiosis and improves chicken health.

\section{References}

1. Krutchen T (2012) Poultry Agriculture. National Agricultural Statistics Service (NASS) Agricultural Board, USA department of Agriculture. pp. 27.

2. Food and Agriculture Organization (FAO) (2012) Meat and meat product and sources of meat. Agricultural and consumer protection Department of Animal production and Health. pp. 12.

3. Al-Naseer A, Al-Khalaifa H, AL-Saffar A, Khalil F, Al- Bahouh, et al. (2007) Overview of chicken taxonomy and domestication. World Poultry Science Journal 63(2): 285-300.

4. Okonkwo WL, Akubuo CO (2001) Thermal analysis and evaluation of a passive solar energy poultry chicks brooder. Nigerian Journal Review (9):73-78.

5. D'Mello JPF (1995) Leguminous leaf meals in non-ruminant nutrition. ( $1^{\text {st }}$ edn.), AB International Walling Font Oxon, Uk. pp. 247-280.

6. Oluyemi JA, Roberts FA (2000) Poultry Production in Warm Wet Climates. ( $\left.2^{\text {nd }} e d n\right)$, Spectrum Books, Ibadan, Nigeria. p. 190.

7. Ogbu CC, Onuh OS (2015) Oocyst output, performance and haematological indices of broiler chickens infected with coccidian Oocysts and fed Ocimum gratissimum leaf extract. Global Journal of Poultry Farming and Vaccination 3(2): 146-153.

8. Duszynski DW, Couch L, Upton SJ (2016) The Coccidia of the World.

9. Nghonjuyi NW, Kimbi HK, Keambou CT, Manka'a CN, Toukala JP, et al. (2015a) Assessment of anti-coccidial efficacy of ethanolic extract of Aloe vera leaf in Kabir chicken in Cameroon. The Journal of Advances in Parasitology 2(2): 23-29.

10. Arczewska-Włosek A, Światkiewicz S (2015) The efficacy of selected feed additives in the prevention of broiler chicken coccidiosis under natural exposure to Eimeria spp. Annals of Animal Science 15(3): 725735 .

11. Pourali M, Kermanshahi H, Golian A, Razmi GR, Soukhtanloo M (2014). Antioxidant and anticoccidial effects of garlic powder and sulfur amino acids on Eimeria infected and uninfected broiler chickens. Iranian Journal of Veterinary Research 15(3): 227-232.

12. Williams RB (2006) Tracing the emergence of drug-resistance in coccidia (Eimeria spp.) of commercial broiler flocks medicated with decoquinate for the first time in the United Kingdom. Veterinary and Parasitology 135(1): 1-14.

13. Nwosu CO, Yahayah K, Igbokwe OI (2011) Toxicity and Anticoccidial Efficacy of Some Plants Used in the Traditional Treatment of Avian coccidiosis in Semi-arid North Eastern Nigeria. Research Journal of Parasitology 6(1): 18-30.

14. El-Khtam AO, El Latif AA, El-Hewaity MH (2014) Efficacy of turmeric (Curcuma longa) and garlic (Allium sativum) on Eimeria species in broilers. International Journal of Basic and Applied Sciences 3(3): 349356.

15. Nghonjuyi NW, Tiambo CK, Kimbi HK, Manka'a CN, Juliano RS, et al (2015b) Efficacy of ethanolic extract of Carica papaya leaves as a substitute of Sulphanomide for the control of coccidiosis in kabir chickens in Cameroon. Journal of Animal Health and Production 3(1): 21-27.

16. Parekh J, Chanda S (2006) Antibacterial and phytochemical studies on twelve species of Indian medicinal plants. African Journal of Biomedical Research 10(2): 175-181.

17. Soulsby EJL (2002) Helminths Arthropods and Protozoa of Domesticated Animals. ( $7^{\text {th }}$ edn), Bailliere Tindall, London, UK. pp. 573-574.

18. Slaoui M, Fiette L (2011) Histopathology procedures: from tissue sampling to histopathological evaluation. Methods Mol Biol 691: 6982.

19. El-Banna HA, Amera AE, Soliman M (2012) Anticoccidial Activity of Allium Sativum and Aloe vera in Broilers. International Journal for Agro Veterinary and Medical Sciences 7(4): 117-125.

20. Biu AA, Yusuf SD, Rabo JS (2006) Use of neem (Azadirachta indica) aqueous extract as a treatment for poultry coccidiosis in Borno State, Nigeria. African Scientist 7: 147-153.

21. Tan GH, Long K (2012) Preliminary study of anticoccidial activity of medium chain fatty acids (MCFA) and their corresponding monoglycerides on broiler chicken coccidiosis. International Journal of Biotechnology 1(2): 134-141.

22. Allen PC, Danforth HD (1998) Effects of dietary supplementation with n-3 fatty acid ethyl esters on coccidiosis in chickens. Poult Sci 77(11): 1631-1635.

23. Allen PC, Danforth HD, Augustine PC (1998) Dietary modulation of avian coccidiosis. Int J Parasitol 28(7): 1131-1140.

24. Sikkema J, De Bont JAM, Poolman B (1995) Mechanisms of membrane toxicity of hydrocarbons. Microbiol Revi 59(2): 201-222.

25. Saif YM, Barnes HJ, Glisson JR, Fadly AM, McDougald LR, et al. (2003) Diseases of poultry. $\left(11^{\text {th }}\right.$ edn), Iowa State Press, A Blackwell Publishing Company. pp. 52 - 57.

26. Conway DP, Sasai K, Gaafar SM, Smothers CD (1993) Effects of different levels of oocyst inocula of Eimeria acervulina, E. tenella, and E. maxima on plasma constituents, packed cell volume, lesion scores, and performance in chickens. Avian Diseases 37(1): 118-123. 
27. McDougald LR (2003) Coccidiosis. In: Saif YM, Barnes HJ \& Fadly AM, et al. Poultry Diseases. Iowa State Press, Iowa. pp. 947-991.

28. Chapman HD, Marsler P, LaVorgna MW (2004) The effects of salinomycin and roxarsone on the performance of broilers when included in the feed for four, five or six weeks and infected with Eimeria species during the starter or grower phase of production. Poult Sci 83(5): 761-764.
29. Jatau ID, Odika AN, Thlama M, Talba AM, Bisalla M, et al. (2014) Response of 2 breeds of broiler chicks to experimental infection with low dose of Eimeria tenella sporulated oocysts. Turkey Journal of Veterinary and Animal Science 38: 398-404.

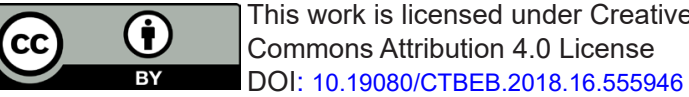

\footnotetext{
Your next submission with Juniper Publishers will reach you the below assets

- Quality Editorial service

- Swift Peer Review

- Reprints availability

- E-prints Service

- Manuscript Podcast for convenient understanding

- Global attainment for your research

- Manuscript accessibility in different formats ( Pdf, E-pub, Full Text, Audio)

- Unceasing customer service

Track the below URL for one-step submission

https://juniperpublishers.com/online-submission.php
} 